\title{
The effects of neotectonic and hydrological processes on the flood hazard of the Tisza region (East Hungary)
}

\author{
G. Timár ${ }^{1}$ and T. Rácz ${ }^{2}$ \\ ${ }^{1}$ Space Research Group, Dept. of Geophysics, Eötvös University of Budapest, Hungary \\ ${ }^{2}$ Hidrometra Hydraulic Engineering Ltd, Budapest, Hungary
}

Received: 11 January 2002 - Accepted: 12 June 2002

\begin{abstract}
The area crossed by the Tisza River has been continuously subsiding during the Quaternary and is filled up by sediment of the rivers flowing from the Carpathians. The average Quaternary subsidence rate was multiplied by the increased sediment compaction caused by the water and hydrocarbon exploitation after river regulation. The rate of this subsidence shows a characteristic spatial variation. In the most subsiding areas this process increases the effect of the silting up of the floodway between the dykes and the occurrence of thresholds in the longitudinal profile. These processes influence the mid- and long-term flood security of the region and a solution system is proposed here to handle the increased flood hazard. Besides this, the geomorphology of the Mid-Tisza region is shown by a detailed digital elevation model of a smaller area offering a tool for the re-assessment of the plans of flood control systems.
\end{abstract}

\section{Introduction}

The flood events during the last few years turned the attention to the hydrological security of the Tisza region. Every year produced a new maximum of the water level at least at one section of the river. Rapid cloudburst-like rainfall on the headwaters of the catchment induced the floods of November 1998 and March 2001 while classic snowmelt floods took place in the spring of 1999 and 2000. While the rainfallinduced floods took only a few days endangering only the upstream section of the Tisza River (and causing the only dyke rupture at the Hungarian section during this four years), the snowmelt caused lasting floods endangering mainly the downstream part of the river, especially the area of Szolnok.

Surprisingly, there were no significant new maxima of the water discharge during this period. Concerning the previous biggest flood events, in 1970 and 1979 the peak discharge

Correspondence to: G. Timár (timar@ludens.elte.hu) was almost the same as in 1999 (at Szolnok ca. $2400 \mathrm{~m}^{3} / \mathrm{s}$ ). The peak water level connected to them at the same place rose more than half meter. Another $200 \mathrm{~m}^{3} / \mathrm{s}$ discharge surplus caused an additional $70 \mathrm{~cm}$ rise in the peak water level in 2000. The hydro-meteorological conditions were quite far from the worst-case scenario in these years: the significantly greater volumes of snow were present at the catchment in 1999 and 2000 but its melting didn't coincided with heavy rains.

In case of the Tisza River, the complex system of tributaries can lead to quite strange effects, e.g. significant banking up or even a reversed advance of the flood peak (Vágás, 2000). The situation in 1999 and 2000 was different: the Tisza itself banked up the tributaries' lower waters. There are serious indications that the new peaks of water level occuring at non-maximum discharges are caused by the decreased water conductivity of the river channel and also a "mysterious" banking up downstream of Szolnok that occured in 1999-2000 but hadn't been detected in 1970 (Kovács and Vári-Szőllősi, 2001).

It has to be underlined that this study shows no new geological or hydrological data but conjugates existing and published ones, connects these latter hydrological effects to known geological and geomorphic processes for better understanding of the flood behaviour and to propose solutions to raise the long-term flood security of the Tisza region.

\section{Quaternary geology of the Great Hungarian Plain: an overview}

The origin of the formation of the Pannonian Basin (PB) is an eastward extension induced by the gravitational collapse of the Alpine orogenes (Ratschbacher et al., 1991). This process started in the Early Miocene and worked simultaneously with the eastward advance of the Carpathian subduction zone (Horváth, 1993). The possibility of the further eastward ex- 


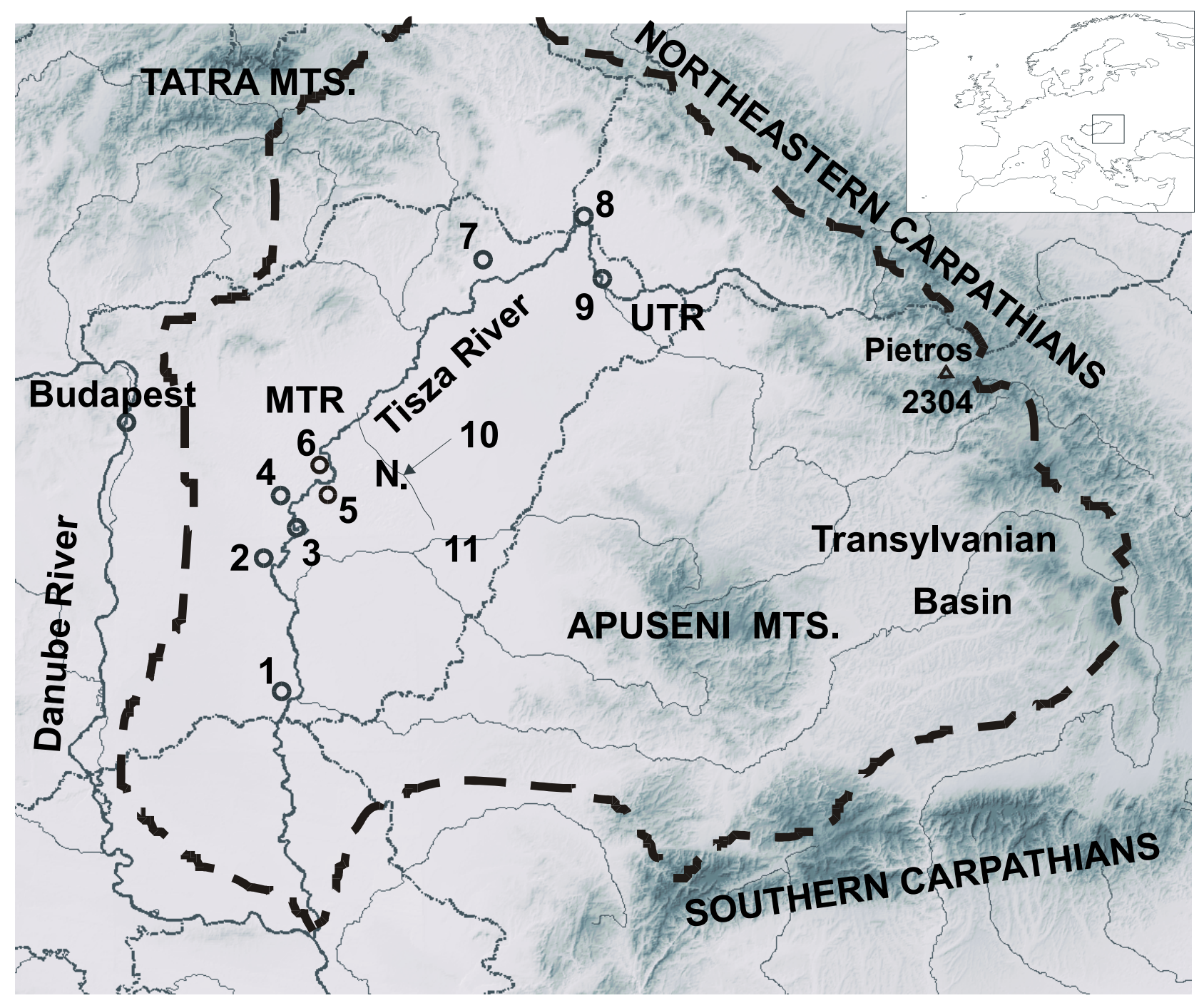

Fig. 1. The Great Hungarian Plain and the Tisza catchment. 1 = Szeged; 2 = Tiszakécske; $3=$ Vezseny; $4=$ Szolnok; 5 = Törökszentmiklós; 6 = Nagykörü; $7=$ Tokaj; 8 = Záhony; 9 = Vásárosnamény; $10=$ the ancient Mirhó (natural flood channel); $11=$ Körös River; N. = the Nagykunság area; MTR = Mid-Tisza Region; UTR = Upper Tisza Region. Dashed line indicates the border of the cacthment area.

tension was stopped when the Carpathian zone reached the East-European craton that could not have been subducted, thus the Pannonian region started to invert tectonically. This pression caused - and causing even nowadays - the buckling of the Pannonian litosphere, and inducing the starting of the uplift in the western and eastern thirds of the PB (Transdanubia and the Transylvanian Basin) while the central part, the Great Hungarian Plain (GHP) remained subsiding (Horváth and Cloetingh, 1996) and this subsidence remained active in the Quaternary. Supposing that the subsidence and the sedimentation was continuous, the absolute value of the subsidence can be estimated based on the thickness of the Quaternary sediments (data of Franyó, 1992; cf. Fig. 2). The only subsidence history model for the GHP (Kretzoi and Krolopp, 1972; based on fossils and palaeoenvironment reconstruction) describes continuous subsidence vith varying speed. The estimation of the speed of subsudence based on the Quaternary sediment thickness can be only a qualitative one because of omitting the effects of compaction, so any figures mentioned below, based on layer thicknesses, are lower absolute estimations for the subsidence rate. Besides, the definition of the Pliocene-Quaternary boundary is still a subject of an unclosed discussion, the values shown in Fig. 2 can be affected by error of $50 \%$ but the distribution of the thickness is a good model of the reality.

The thickness of the Quaternary sediments shows a characteristic spatial variation in the GHP, as the basin-forming processes mentioned above have not stopped during this period. The neotectonism of the GHP can not be clearly investigated using historical earthquake data (Tóth et al., 1995). In the historical times the quickly subsiding zone was sparsely populated and there were only a few permanent buildings because of the regular inundulation, therefore the small and even medium size eartquakes - if they occurred anyway - 


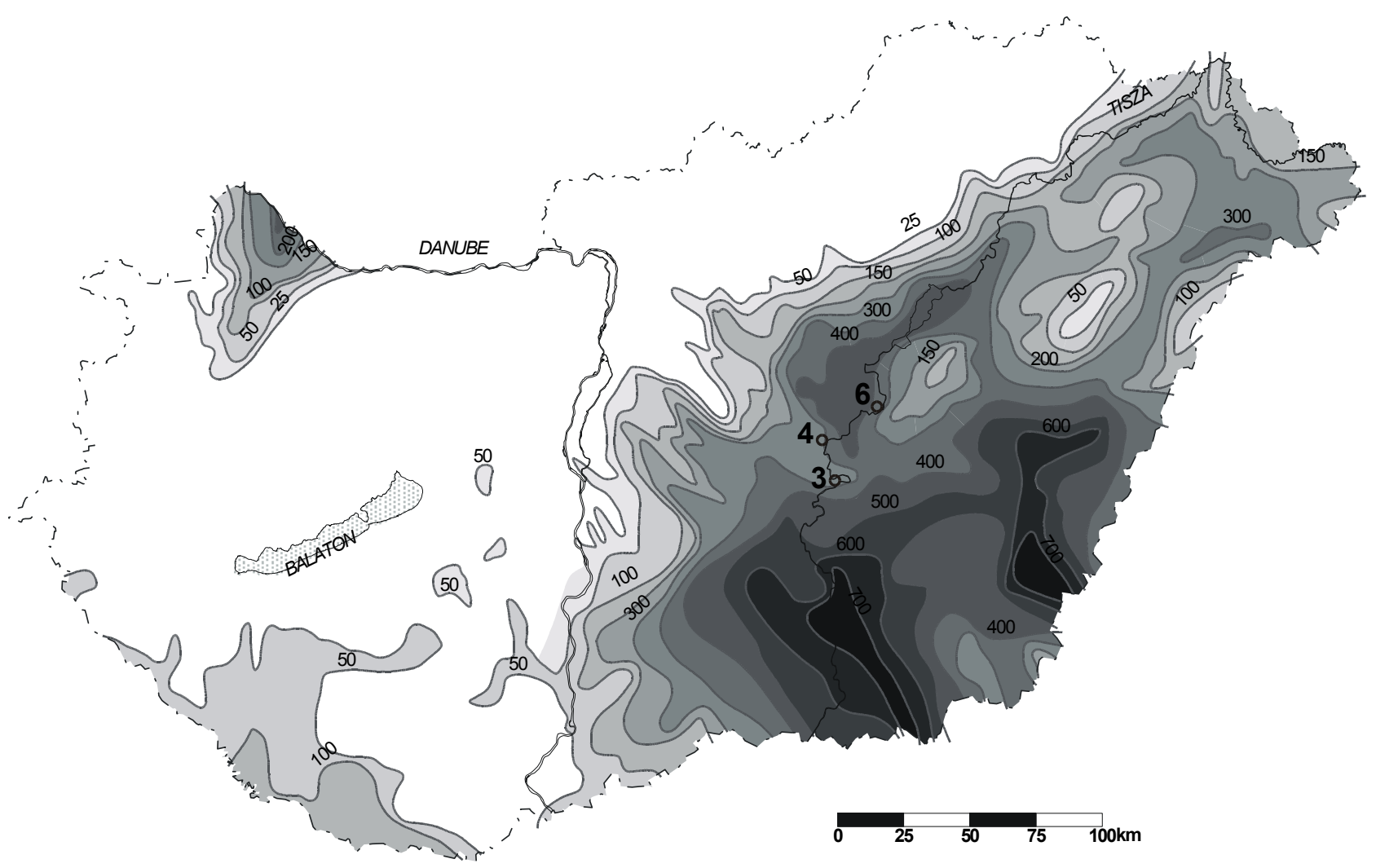

Fig. 2. Thickness of the Quaternary sediments in Hungary, after Franyó (1992). Location code numbers are similar to the ones on Fig. 1.

were not noted. Neotectonic activity of the area can be traced by river planform analysis and, especially for this area, based on data of Mike (1975), Schumm et al. (2000) showed the activity of some deformation zones using river avulsion analysis.

The total volume of the sediments represented on the Fig. 2 is about $7-8000 \mathrm{~km}^{3}$ on the territory of Hungary and is almost totally of fluvial origin. As this is the volume of compacted sediments, the total aggradation has even higher figures. Concerning the climate change in the Tisza catchment during the Quaternary (Gábris, 1998) and the uknown subsidence rate at a given place and time, the speed of the sedimentation was varying. The ratio of the sediment thickness and the geological time leads to a lower estimation of the average subsidence rate of $0.2-0.3 \mathrm{~mm} / \mathrm{year}$ in the central and southern part of the GHP. Along the present rivercourse of the Tisza River, at the vicinity of the Vezseny section this speed is smaller; around $0.15 \mathrm{~mm} /$ year (cf. Fig. 2). This uneven subsidence results a long-profile threshold of a few meters during 1000 years that is easily levelled by the river. The longitudinal profile of the pre-regulation Tisza River (Bogdánfy, 1906) shows no correlation to the subsidence rates computed on the basis of Quaternary sediment thicknesses; thresholds due to the uneven subsidence could not occur because of the significantly quicker channel-forming processes and also because of the self-organization of the river meandering (Stølum, 1996).

\section{Geomorphology of the Mid-Tisza region: fluvial levels and terraces}

The Tisza, the trunk river of the GHP drains $157000 \mathrm{~km}^{2}$, its catchment area covers the eastern part of the PB. The highest point of the Mid-Tisza catchment area is the Pietros $(2304 \mathrm{~m})$ in the Rodnei Mts. The Tisza itself originates in the Northeastern Carpathians and reaches the GHP near the Hungarian border (see Fig. 1). The mean discharge of the river at Tokaj (the downstream end of the Upper Tisza region) is about $400 \mathrm{~m}^{3} / \mathrm{s}$ and rises to $800 \mathrm{~m}^{3} / \mathrm{s}$ at Szeged because of the tributaries. Major floods occur in the spring season due to snowmelt on the mountains of the catchment. Local flood events connected to heavy rains occur in almost every months on smaller parts of the upper catchment.

The continuous Quaternary subsidence mentioned earlier enabled the formation of one of the world's most developed floodplains on the GHP: the Tisza river system. It is almost - but not fully! - flat: the elevation difference along the river is less than $20 \mathrm{~m}$ on distance of $200 \mathrm{~km}$. On the GHP the longitudinal profile of the pre-regulation Tisza River has only minor changes (Bogdánfy, 1906; Lászlóffy, 1982).

Looking at a small or medium scale map one can think that the GHP is completely flat without significant topography. From a certain point of view it can be true. But in the meterdecimeter vertical resolution of the hydraulic planning the GHP and especially the vicinity of the rivers has surprising relief. 


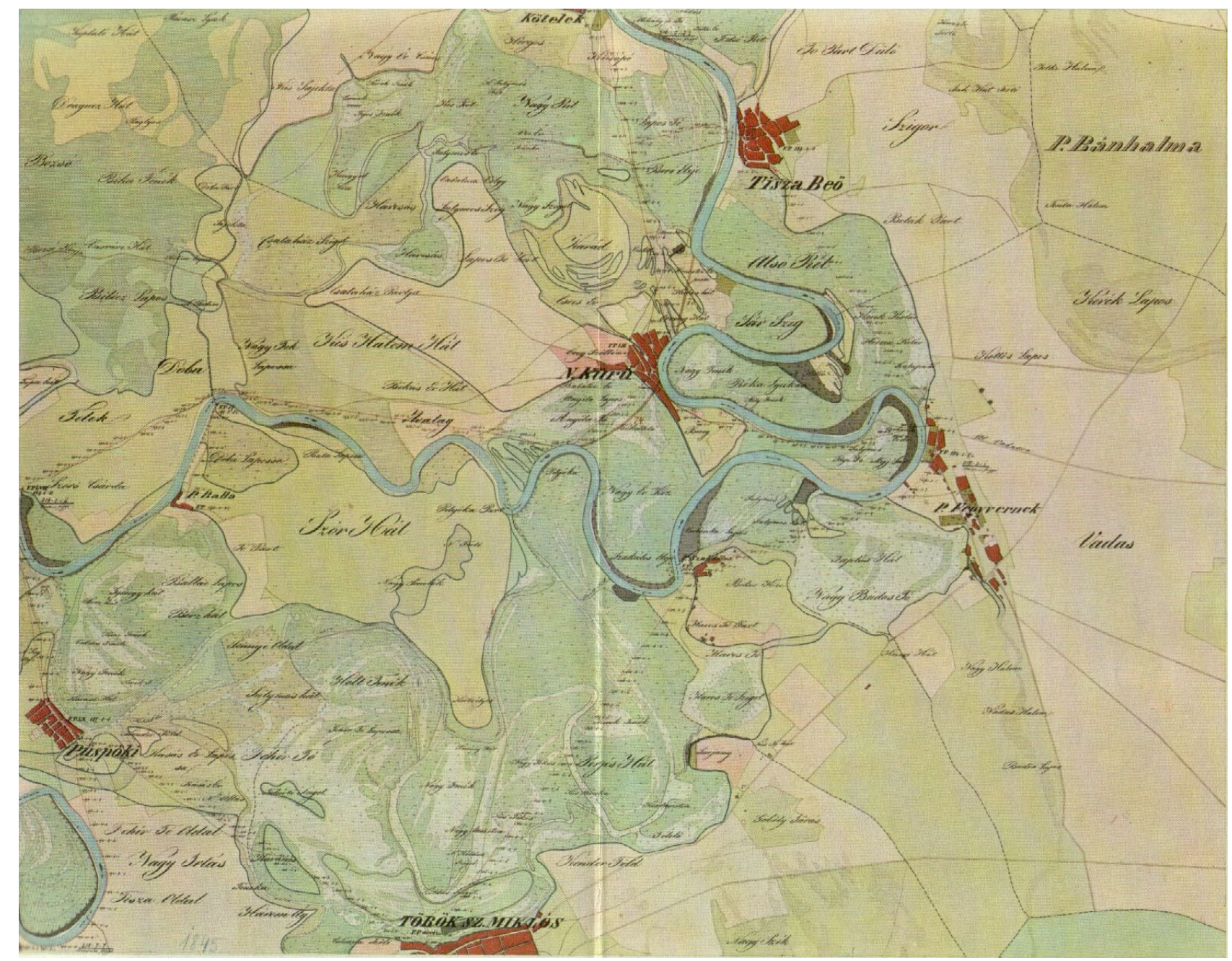

Fig. 3. The Nagykörú region in the map of Sámuel Lányi (1845). Published by Sugár (1989). Width of the mapped area is about 20 km.

Historical maps made for the preparations of the river regulation works (Sugár, 1989) show that the river banks are followed by the meander belt and its width can be several kilometers. This low meanderbelt was reached by the floods regularly (low floodplain: the greenish area on the Fig. 3) and followed by the high floodplain and the flood-free terrace, respectively (yellow area on the Fig. 3); the elevation difference between them is $2-4 \mathrm{~m}$ (Fig. 4).

The historical settlements are all on the flood-free terrain and the escarpments are clearly visible in the backyards following the last buildings of these towns and villages. The most evident example is in the town of Törökszentmiklós there is a clear escarpment on the northern side on the National Road No. 4, 10-20 m from the road. The northern quarter of the town is situated on the low floodplain (Fig. 5)! These fluvial levels can be found in the whole Hungarian section of the Tisza River downstream of Tokaj (Pécsi, 1959; Gábris, 1998).

Figure 4 shows a digital elevation model (DEM), constructed using topography maps with a scale of 1:10000, digitizing the $1 \mathrm{~m}$ base and $0.5 \mathrm{~m}$ halving contours. The hor- izontal resolution of this DEM is $10 \mathrm{~m}$, the vertical precisity is $1 \mathrm{~m}$. Comparing Figs. 3 and 4 it is apparent that on the historical maps the borders of the fluvial levels are precisely shown.

It is important to mention that concerning the width of the regularly inundulated floodplain, the Nagykörú area, shown on the Fig. 4, is not typical; this terrain level is much more wider elsewhere. Along the line of Abádszalók-Kisújszállás (along the flood-conducting natural channel of Mirhó, and its continuation) the low floodplain of the Tisza is connected to the Körös River system, indeed (Lászlóffy, 1982).

\section{The regulation of the Tisza River: economical benefits vs. increased flood hazard}

The details of the water control works on the Tisza River are well known (e.g. Lászlóffy, 1982), its description is beyond the scope of this short study. Its goals are listed here, complemented with the results. 


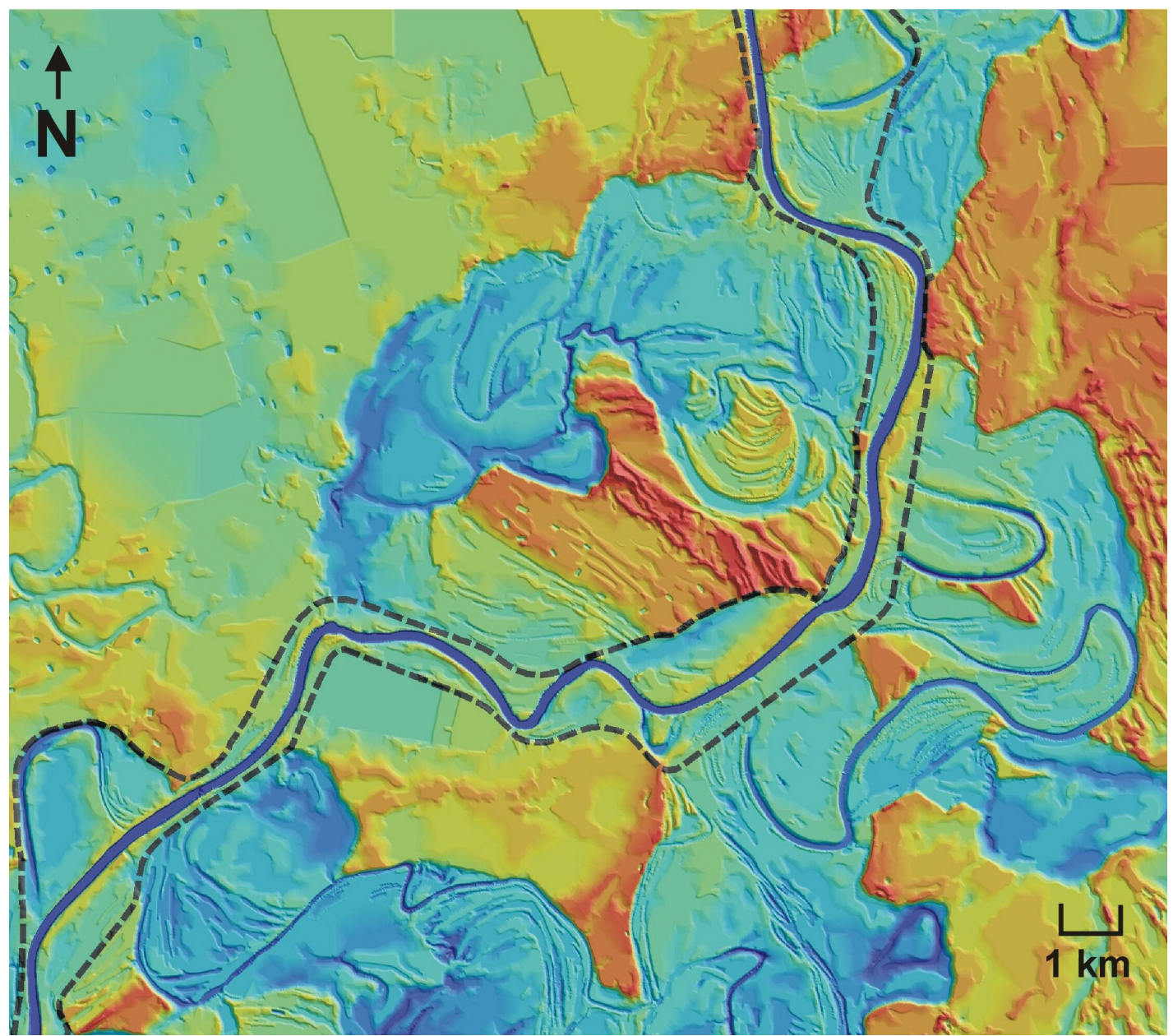

Fig. 4. Digital elevation model of the Nagykörü region. The dark blue area is $81 \mathrm{~m}$, while the red one is $93 \mathrm{~m}$ above sea level. The present flood control dykes are shown by dashed black lines.

Before the construction of the Hungarian railroad network in the second part of the 19th century, there was an urging claim to create high-capacity transport lines, mainly for the forwarding of agricultural goods, especially crops. The periodic inundulation of a considerable part of the GHP (about $20000 \mathrm{~km}^{2}$, one fifth of its territory) prevented agricultural activity and production. Moreover, there was a general fear in the public of the big floods at the beginning of the 19th century.

The regulation of the rivers of the area offered a good solution for these problems. The water control meant the construction of flood control levees, separating the floodplain to a floodway and a protected terrain. This was supplemented by the cutoffs of the larger curves of the river channel for a quicker flood transport and also for easier navigation. In the plans the minimum width of the floodway was set to $760 \mathrm{~m}$ but even nowadays there are bottlenecks of $300-400 \mathrm{~m}$ (Lászlóffy, 1982).

As a result of the river control works the region, regularly inundulated before (mainly the territories relatively far from the rivers, the Nagykunság and the Körös area) was claimed to the agricultural production, and as a "second land con- quest", it gave an opportunity for an explosion-like population growth of the GHP at the end of the 19th century.

While the transport lines (rivers capable for navigation and the railroad network) were constructed, the agricultural production expanded spatially and grew rapidly, the type and the nature of the flood hazard changed, and the flood security of the settlements was not increased reassuringly. As the water level became more sensible to the discharge on the rivers - fit between the dykes close each other -, the flood peaks reached maximums never seen before. The problem became apparent to the public after the famous flood of 1879 damaging heavily the town of Szeged but the tools of resolution eliminating the bottlenecks, constructing higher and stonger dykes - haven't changed until now. The rising in the level of the flood peaks continued in the 20th century and the last and largest snowmelt floods of 1999 and 2000 showed that there is no reserve in the flood defense system using only these tools.

It should be also noted that the basic concept of flood regulation, the fast conduction of the floods, altered the water system and the water balance of the GHP significantly; often there is a serious drought in the summer and agricultural 


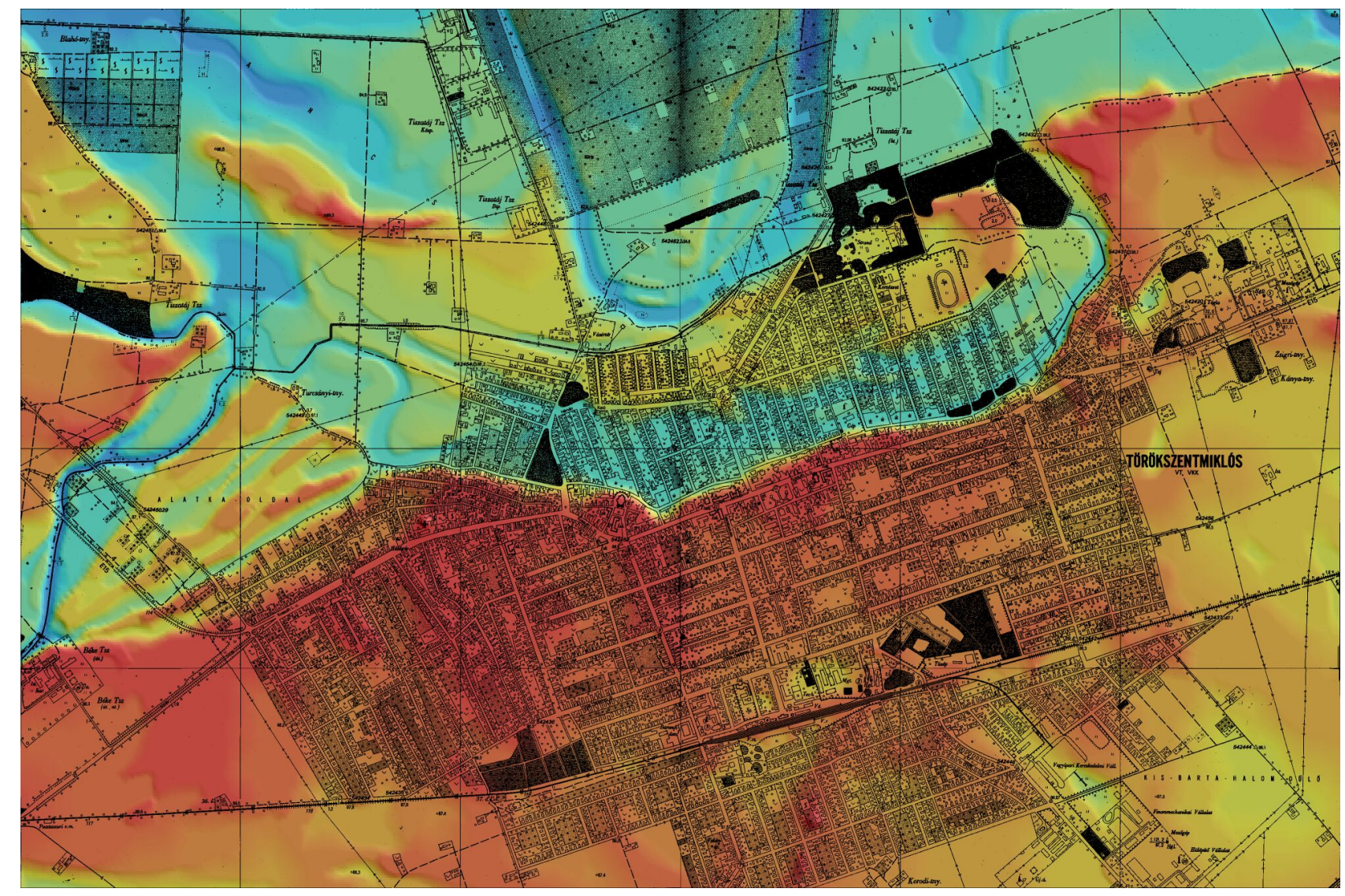

Fig. 5. The city of Törökszentmiklós is built partially on the low floodplain (blue), after the water control works of the Great Hungarian Plain. The low floodplain is open to the Tisza River, and protected by only one dyke. The elevation difference of the escarpment is $6 \mathrm{~m}$. One-kilometer grid is represented. The National Road No. 4 follows the higher (red) side of the escarpment.

production requires irrigation via the use of artificial canal systems.

\section{Changes in evnironmental conditions of the Tisza Plain in the 20th century}

Environmental conditions of the Tisza catchment changed considerably after the completion of the main part of the flood control works. Considering the huge literature of the subject, here we only mention and not detail the effects of deforestation in the mountains of the catchment, the quicker assembling of the floods and the decrease in the preparation time adventage. As the sediment discharge of the floods increased because of the deforestation, we consider the spatially limited sedimentation (Schweitzer, 2001), the accelerated uneven subsidence of the GHP and the increased weather variances as the processes most effecting the longterm flood security.

The Quaternary subsidence speed of the GHP is now obsoleted: the results of repeated precise levelling between 1950 and 1980 show that this speed was multiplied (Joó, 1992). The causes of accelerated subsidence can be tied to water and hydrocarbon exploitation. It is apparent on Fig. 6 that the quickly subsiding zones are in the vicinities of the oil and gas fields and the cities. The most subsiding zone is the area of Debrecen, the largest town of the GHP; the terrain level decreases $7 \mathrm{~mm} /$ year there - barely because of the overproduction of the artesian water.

Concerning the reliability of the results of Joó (1992), it should be underlined that they are based on traditional precise levelling of geodesy, therefore the precisity of a single altitude measurement is around one centimeter. The results were derived from repeated measurements with a time difference of ca. 30 years so the error of these data can be estimated around 10\%. It should be mentioned that Joó (1992) gives vertical movement maps of the surface not only to the GHP but to the whole Pannonian-Carpathian region, processing geodetic data from different countries. This could produce further errors but in this study we use only the Hungarian measurement points, therefore a uniform data set.

The negative effects of this process are two different sorts; around a river reach crossing a relatively subsiding zone the protected floodplain, without regular inundulation and therefore without regular sediment supply, subsides quicker than the floodway. This increases the terrain level difference between the floodway and the protected floodplain. The other problem is that as a river crosses a slower subsiding (rela- 


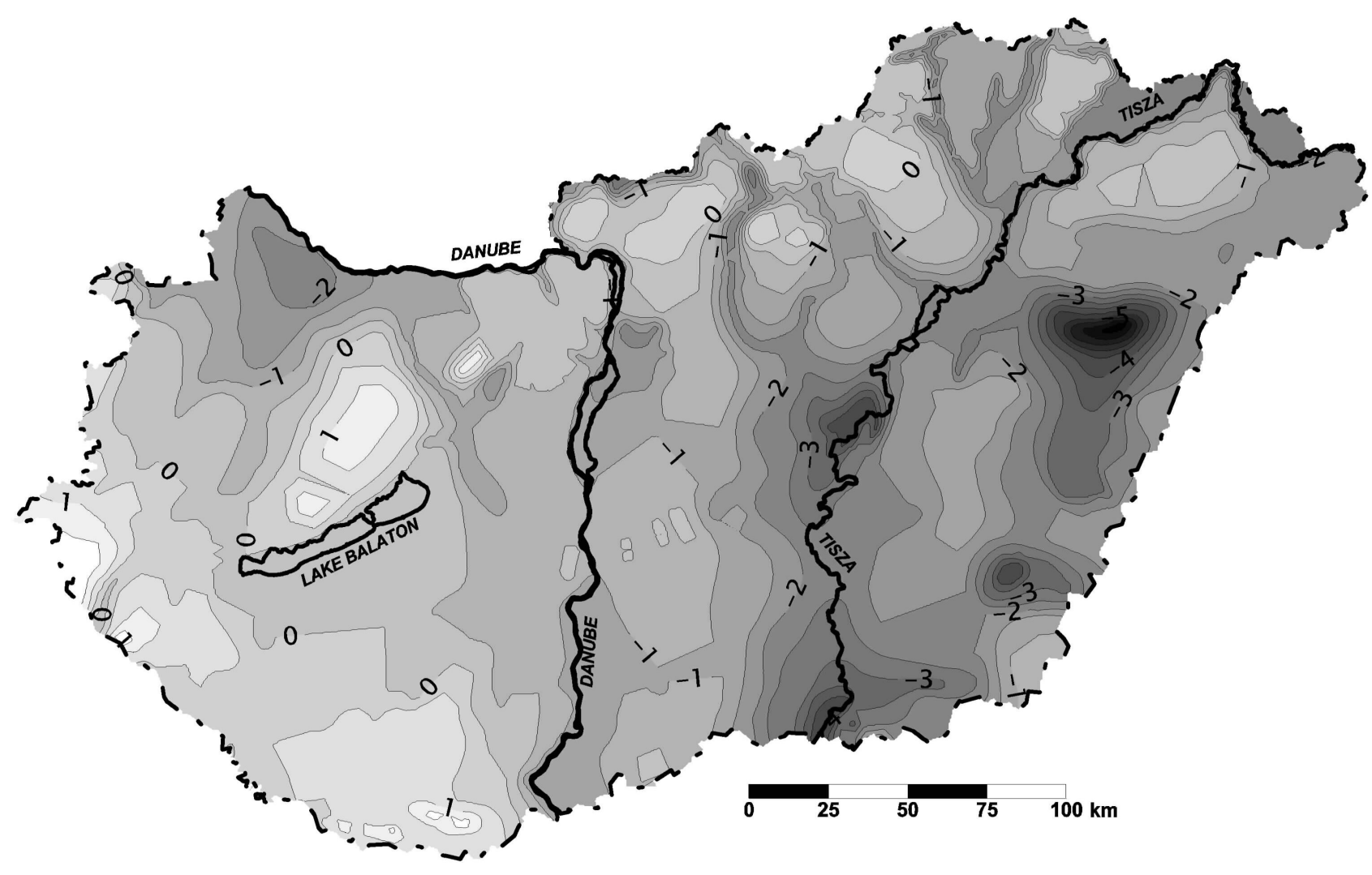

Fig. 6. Recent vertical movements in Hungary; average vertical movement between 1950-1980 in mm/year units, after Joó (1992). Positive numbers indicate uplift. Note that Tisza River crosses quickly and slowly subsiding zones, too.

tively uplifting) zone it has to cross a longitudinal profile threshold that banks up the water and further increases aggradation in the floodway. The most relevant example is the section of the Tisza River between Szolnok and Tiszakécske; the downstream part of this zone is relatively uplifting compared to the faster subsiding upstream part - the null point of the Szolnok watermark "went down" $15 \mathrm{~cm}$ during the last 60 years! This acceleration of uneven subsidence was not induced at the time of the river regulation, and can give one of the possible causes of the "mysterious" banking up mentioned earlier, shown by Kovács and Vári-Szőllősi (2001).

The economic goals of the water control works were achieved (moreover navigation, after the construction of the dense railroad network and partially because of the changes of the international borders, practically ceased on the Hungarian section of the Tisza River). The flood defense regime has to confront changes in environmental conditions in case of the floods of the past years. Fortunately this coincides with the changes in economic conditions in Hungary and Europe.

\section{Decreasing flood hazard in the Great Hungarian Plain: a possible solution}

In this chapter we propose a solution system that could decrease the mid- and long-term flood hazard in the Tisza re- gion, a risk that is caused by the quickened and uneven subsidence of the GHP.

The first element of our proposal is to find such a solution that simultaneously increases the water conduction capacity of a river section, decreases the flood peak levels and handles the sediment aggradation without causing quick silting up of the floodway compared to the protected floodplain. The parts of this solution: widening the floodway (to the borders of the low floodplain or meander belt, where possible), increase the hydraulic smoothness and the water storage capacity of the wider floodplain to an acceptable and sustainable level and maintain that with minimum work and strictly eliminate the remained bottlenecks. The large inundulated territory enables the extension of aggradation and decreases the effect of the silting up.

The second element is to designate some parts of the actually protected floodplain as emergency reservoirs. The concept of emergency storage is to conduct the water of the flood peak at a precalculated time to a dam-encircled reservoir. This causes the high water stage to be longer but the water level of the peak becomes considerably lower than without using these reservoirs. It is apparent that considering the peak discharge of the Tisza river, a few hundred $\mathrm{m}^{3} / \mathrm{s}$ of water should be stored during the flood peaks to reach a significant change of the flood profile. This claims for the construction of strong dykes capable of preventing secondary flood events (wetting through etc.), around the reservoirs. Emer- 
gency water storaging on the low floodplain is favourable for the spatial extension of aggradation in a controlled system. Furthermore, it is quicker to construct emergency reservoirs than a new dyke system along the river.

It must be mentioned that the Hungarian government and its institutions are working on a new concept, named after the planner of the original regulation "Improvement of the Vásárhelyi-Plan". This concept considers the elimination of all major bottlenecks, the construction of new flood conducting channels and emergency reservoirs.

As it is shown on Fig. 4 the width of the low floodplain along the river is varying between 1 and $5 \mathrm{~km}$. The terrain level there is $2-4 \mathrm{~m}$ lower than on the flood-free (high bank) terrain. To fill up this level difference the aggraded sediment load of cca. one thousand big floods is required and this volume means enough reserve also for the emergency storage. As the water inundulates a wider floodway, its peak level falls as a function of the downstream bottlenecks and the hydraulical smoothness and storage capacity of the floodway. The newly construced dykes located on the high banks at the boundary of the low floodplain, can be lower and should be prepared to lasting but lower water pressure.

This concept can not be generalized for the whole region of the Tisza River. Where the low floodplain draws away the river (e.g. at the Nagykunság), the floodway has to be delimited by dykes more distant from the channel but built following the present concept. Settlements built on the low floodplain have to be protected as possible, but the construction of exempting, flood conducting and bypassing channels might be necessary there. Another claim is to decrease to banking up of the bridges and systematic construction of the floodway apertures along the linear structures e.g. the roads.

Inside a wider floodway, the reconstruction of meander curves cut-off during the regulation, or at least of a part of its set, as a low-water channel has to be considered. On a floodway wide enough, the original sinuosity of the channel is restored, anyway, by the river itself without active regulation (Stølum, 1996). Besides, it is essential that the floods cannot be forced to do meanders: the flood conducting channel(s) has to be as straight as possible. The quick conduction of the floods has to be helped by meadows and pastures with high hydraulical smoothness, their maintenance is an important task. The settlement development on the low floodplain has to be restricted or even forbidden as it was tried by the policies after the floods and excess water damages of the last years.

The upper reach of the Hungarian section of the Tisza River has to be handled differently because of the different environmental settings. Upstream of Záhony - decreasingly to the downstream - the river builds actively its own alluvial fan. On the Ukrainian section this causes a significant lateral migration of the channel but even in Hungary limiting of alluvial fan building to a narrow land between dykes is highly questionable. This flood defense problem is worsen by the short preparation time adventage that is now only one day after the precipitation peak. The Upper Tisza region cannot be protected in long term by regular flood control levees along the rivers - the settlements have to be surrounded be circular dykes but the other territories have to be given up to the inundulation in order to protect safely the towns and villages themselves.

Without human activity, riperian forests, mainly willows are grown on the floodway; their smoothness is low, only one third-one fifth of the channel itself (Benini et al., 1979). Because of its huge territory, the regular mowing of the floodway is out of question - planting poplar woods in geometrical order produces higher smoothness but also a strange landscape. Our proposal is to form one or more, $80-100 \mathrm{~m}$ wide channels of meadows and pastures with high hydraulic smoothness for the flood conduction on both riversides, kept free of dense vegetation by grazing. Thus the transformation of the mainly wood-covered, regularly inundulated floodways can be a basis of the tourism and gives an opportunity for traditional floodplain agriculture.

The proposed changes mentioned before involve a serious reconstruction of the infrastructure and the economy of the area to be "given back" to the river floodway or assigned as emergency reservoirs. Its costs are significantly higher than the price of the dyke strenghtening so the decision has to be made on political level and has to have local public support. This is a much more complex problem than any engineering task and the last four years' series of floods could be a base for a change in mentality.

\section{Conclusions}

The Great Hungarian Plain and the Tisza River gives a nice example that recent vertical movements (based on either crustal processes or compaction) can significantly and quickly affect the flow characteristics of a river. In case of the GHP, the recent subsidence has three components: crustal movements of neotectonic origin, natural compaction of the thick basin fill sediments and compaction induced by hydrocarbon and artesian water exploitation. The latter one of the three is the largest component and it has been operating only since the river regulation works. Unregulated rivers with natural conditions "handle" these kind of changes by altering their own planform and by extent inundulation and sediment aggradation during floods. Regulation limits the reaction potential of rivers: deformations occur in the longitudinal profile producing banking up during floods and increasing the risk of inundulation of the artificially protected territories.

Acknowledgements. This study was carried out in the framework of a project sponsored by the Hungarian Space Office and the Ministry of Transport and Water Management (TP 094) and was also supported by the DFG Collaborative Research Center (SFB 275 TP B1). The map of Fig. 5 and the digital elevation model on Figs. 4 and 5 has been compiled using maps whose content is owned by the Institute of Geodesy, Cartography and Remote Sensing (FÖMI) and published with its permission. 


\section{References}

Benini, G., Cerutti, G., De Philippis, A., Gerbella, E., and Valenziano, S.: Influence of willow-groves and other vegetation types on the waterflow of the mid-reach of the Po River (in Italian). Collana Verde (Ministero Agr. e Foreste, Repubblica Italiana, Roma), 50, 1-46, 1979.

Bogdánfy, Ö.: Hydraulics of natural reaches (in Hungarian). Franklin Society, Budapest, 1906.

Franyó, F.: Thickness of Quaternary sediments in Hungary. Map, scale of 1:500000, Hungarian Geological Institute, Budapest, 1992.

Gábris, Gy.: Late glacial and post glacial development of drainage network and the paleohydrology in the Great Hungarian Plain, in: Bassa, L. and Kertész, Á. (Eds.): Windows on Hungarian Geography. FKI, Budapest, 23-36, 1998.

Horváth, F.: Towards a mechanical model for the formation of the Pannonian Basin. Tectonophysics, 226, 333-357, 1993.

Horváth, F. and Cloetingh, S. A. P L.: Stress-induced late-stage subsidence anomalies in the Pannonian basin. Tectonophysics, 266, 287-300, 1996

Joó, I.: Recent vertical surface movements in the Carpathian Basin. Tectonophysics, 202, 129-134, 1992.

Kovács, S. and Vári-Szőllősi, I.: Results of flood measurements and processing at the Mid-Tisza section (in Hungarian). Proceedings of Int. Conference on Water and Nature Conservation in the Danube-Tisza River Basin, Hungarian Hydrological Society, 19-21 Sept 2001, Debrecen, Hungary, 416-425, 2001.

Kretzoi, M. and Krolopp, E.: Upper Pliocene and Quaternary stratigraphy of Great Hungarian Plain according to palaeontolog- ical data (in Hungarian with German abstract). Földrajzi Értesíto 21, 133-151, 1972.

Lászlóffy, W.: The Tisza River - Waterworks and water management in the drainage basin of the Tisza (in Hungarian). Akadémiai Kiadó, Budapest, 1982.

Mike, K.: Utilization of the analysis of ancient river beds for the detection of Holocene crustal movements. Tectonophysics, 29, 359-368, 1975.

Pécsi, M.: Origin and geomorphology of the Danube Valley, Hungary (in Hungarian). Akadémiai Kiadó, Budapest, 346 p, 1959.

Ratschbacher, L., Frisch, W., Linzer, H. G., and Merle, O.: Lateral extrusion in the Eastern Alps, part 2: Structural analysis. Tectonics, 10(2), 257-271, 1991.

Schumm, S. A., Dumont, J. F., and Holbrook, J. M.: Active tectonics and alluvial rivers, Cambridge Univ. Press. (Chapter 7: Lateral response; Pannonian Basin, Hungary), 175-178, 2000.

Schweitzer, F.: Geomorphological aspects of river regulation and flood control measures - Development of the floodplains of the Hungarian rivers and their connection with the floods and flood control levees. (in Hungarian with English abstract). Földrajzi Értesíto 50, 63-72, 2001.

Sugár, I.: Two manuscript maps of the Mid-Tisza region (in Hungarian). Tiszai Téka I., Dobó István Vármúzeum, Eger, 1989.

Stølum, H. H.: River Meandering as a Self-Organization Process. Science, 271, 1710-1713, 1996.

Tóth, L., Mónus, P., Zsíros, T., Kiszely, M., Kosztyu, Z., and Wéber, Z.: Hungarian Earthquake Bulletin. GeoRisk, Budapest, 1995.

Vágás, I.: Advance of rivers' peak water levels during a floodwave (in Hungarian). Hidrológiai Közlöny, 80(1), 45-53, 2000. 